\title{
Competitiveness of Pakistani Fruits in the World Market
}

\author{
Waqar Akhtar*, M. Sharif ${ }^{* *}$ and Hassnain Shah ${ }^{* * *}$
}

\begin{abstract}
This paper examines the global competitiveness of Pakistan's fruit exports (dates, mangoes, and oranges), using revealed comparative advantage (RCA). It also analyzes domestic consumption trends among selected fruits grown by major exporters. Our results indicate that Pakistan has a comparative advantage in fruit exports. Comparing the movement in comparative advantage indices for Pakistan with those of its main exporters/competitors demonstrates that Pakistan has a relatively high comparative and competitive advantage in the production of dates and mangoes. The increasing trend of competitiveness in Pakistan indicates that there is potential for higher growth; given that fruit exports are a potential source of higher exports earnings, there is a need to strengthen competitiveness in this sector.
\end{abstract}

Keywords: Comparative advantage, competitiveness, exports, growth.

JEL Classification: F14, Q17, Q18.

\section{Introduction}

Pakistan's agro-climatic conditions provide a suitable environment for the production of various horticultural crops, as well as a strong comparative advantage in horticulture, as indicated by the sector's rapid growth in the absence of policy interventions. However, the perishability of horticultural products means that the sector requires an efficient processing and marketing infrastructure that is largely lacking in Pakistan (Khan 2000). As a result, the proportion of fruit exported in relation to total production is as low as 5.7 percent.

Faruqee (1995) suggests that trade policy in Pakistan should be based on comparative advantage according to the World Trade Organization

\footnotetext{
* Scientific Officer, Social Sciences Institute (SSI), National Agricultural Research Centre (NARC), Islamabad.

${ }^{* *}$ Chief Scientific Officer/Senior Director, SSI, NARC, Islamabad.

${ }^{* * *}$ Senior Scientific Officer, SSI, NARC, Islamabad.
} 
(WTO)'s Agreement on Agriculture (AoA), under which member countries are required to utilize the benefits of comparative and competitive advantage in the international economy, increasing competition and forcing resources to be allocated more efficiently. Azhar (1995) points out that exploiting Pakistan's export potential of nontraditional commodities will require considerable streamlining in the areas of storage, transportation, and packing. Since globalization has significantly increased competition, compliance with international standards is necessary.

Citrus fruits, dates, and mangoes are Pakistan's most important export fruits, constituting about 78 percent of the total value of Pakistan's fruit exports (Government of Pakistan 2006/07). In the world market, Pakistan accounts for about 11 percent of date exports as the fourth-largest exporter, 5 percent of mangoes as the sixth-largest exporter, and about 1 percent of oranges (Food and Agriculture Organization [FAO] 2008). Given the importance of these fruits as world exports, it is important to investigate their competitiveness in the global market for Pakistan and its main competitors.

From the point of view of trade theory, competitive advantage is a more useful concept than comparative advantage. Competitiveness includes market distortions while comparative advantage assumes undistorted markets (Vollrath 1985, Vollrath and De Huu 1988). With the gradual reduction in trade barriers led by the process of globalization, more emphasis is now being placed on promoting export competitiveness (Prasad 2004). As a founding member of GATT and signatory to WTO, Pakistan has accepted both the opportunity for and challenge of trade liberalization (Akhtar 1999). This paper attempts to measure Pakistan's export competitiveness in selected fruits compared to major international exporters.

The paper is organized as follows. Section II describes the data and indicators used to measure competitiveness, while our results and discussion are given in Section III. Section IV concludes the paper.

\section{Data and Methodology}

In order to calculate the relevant indicators, we have used data on production, exports, and imports (FAOSTAT 2008) for Pakistan and major exporters of selected fruits in relation to total world trade for the period 1995-2005. To gain an idea of the changes in calculated indicators for this sample period, we use a series of three-year-averages: 1995-1997, 19982000, and 2003-2005. 
We use revealed comparative advantage (RCA) to measure export competitiveness for Pakistan and four of the world's largest exporters of the selected fruits (this ranking was based on the volume of exports in 2005). Per capita (apparent) consumption was derived as production plus imports minus exports divided by country population.

Our analysis is based on Balassa's (1965) and Vollrath's (1991) RCA index of competitiveness. These indicators have been used by several sources to determine competitiveness and comparative advantage (Balassa 1989, Scott and Vollrath 1992, Frohberg and Hartmann 1997, Laursen 1998, Hsu and Wann 2001, Ferto and Hubbard 2003, Mahmood 2005. The study concentrates on the following representations: RCA and RCA\#. RCA was developed by Balassa (1965), while the measure RCA\# is an improved version constructed by Vollrath (1991) and used by Bender and Li (2002); it is considered a more sophisticated and comprehensive measure of international competitiveness. It is important to note that the main difference between Vollrath's RCA\# and Balassa's original RCA index is that it prevents double-counting. Thus, using only export data, we define RCA and RCA\#, respectively, as:

$$
\begin{aligned}
& R C A_{i j t}=\left(X_{i j t} / \sum X_{a j t}\right) /\left(X_{i w t} / \sum X_{a w t}\right) \\
& R X A_{i j}=\left(X_{i j} / \sum_{l, l \neq j}\right) /\left(\sum_{k, k \neq i} X_{k j} / \sum_{k, k \neq i l} \sum_{l, l \neq j} X_{k l}\right) \\
& R C A_{i j} \#=\ln R X A_{i j}
\end{aligned}
$$

$\mathrm{RCA}_{\mathrm{ijt}}$ is the index for product $i$ in country $j$ in year $t, X_{i j t}$ represents the export of product $i$ by country $j$ in year $t, \mathrm{X}_{\text {iwt }}$ is the total world export of product $i$ in year $t, \sum \mathrm{X}_{\mathrm{ajt}}$ is the total volume of exports in country $j$ in year $t$, and $\sum \mathrm{X}_{\mathrm{awt}}$ is the total volume of world exports in year $t$.

The RCA index reveals a comparative advantage (disadvantage) in the export of commodity $i$ by country $j$ if the index's value is greater (less) than 1 .

$R X A_{i j}$ is the relative export advantage index, $\sum_{l, l \neq j}$ is is the total exports of the country minus the product considered, and $\sum_{k, k \neq l} \sum_{l, l \neq j} X_{k l}$ is the total exports of the world minus the country considered for analysis. 
$R C A_{i j} \#$ is simply the logarithm of the relative export advantage index. A positive value indicates a comparative/competitive advantage, whereas a negative value indicates a comparative/competitive disadvantage.

\section{Results and Discussions}

Table-1 indicates the export competitiveness of dates for Pakistan and other major date exporters. Pakistan accounts for $11 \%$ of the world's total date exports, the UAE for 35\%, Iraq for 19\%, Saudi Arabia for 17\%, and Iran for $15 \%$ (FAO 2008). For the period under investigation, the results reveal that Pakistan has a relatively high comparative and competitive advantage in the production of dates over other major date exporting countries. However, Pakistan's per capita apparent consumption decreased during 1995-97 to 2003-05 (Table-2). Competitiveness indicators demonstrated that Iran, Iraq, the UAE, and Saudi Arabia had falling RCA values. The trend in per capita consumption reveals that there was an increase in consumption in Iran, Saudi Arabia and UAE, but a decrease in consumption in Iraq.

Table-1: Competitiveness Indicators of Major Date Exporters

\begin{tabular}{lccccccccccc}
\hline $\begin{array}{l}\text { Period/ } \\
\text { Country }\end{array}$ & Pakistan (4) & \multicolumn{2}{c}{ Iran (3) } & \multicolumn{2}{c}{ Iraq (1) } & \multicolumn{2}{c}{ Saudi Arabia (5) } & \multicolumn{2}{c}{ UAE (2) } \\
\hline Indicator & RCA & RCA\# & RCA & RCA\# & RCA & RCA\# & RCA & RCA\# & RCA & RCA\# \\
\hline $1995-97$ & 44.14 & 3.87 & 36.51 & 3.79 & 173.9 & 5.20 & 6.67 & 1.97 & 16.25 & 2.93 \\
$1998-00$ & 69.62 & 4.35 & 25.3 & 3.34 & 8.38 & 2.15 & 4.99 & 1.68 & 19.85 & 3.29 \\
$2003-05$ & 47.89 & 3.95 & 25.24 & 3.37 & 9.85 & 2.32 & 5.97 & 1.88 & 9.13 & 2.33 \\
\hline
\end{tabular}

Source: Computation based on data from www.fao.org. Figures in parentheses indicate the ranking of the country in the world market for dates. RCA = revealed comparative advantage, RCA\# = ln (RXA). 
Table-2 Annual per Capita Consumption of Dates (Unit: $\mathrm{kg} /$ person/annum)

\begin{tabular}{lccccc}
\hline $\begin{array}{l}\text { Period/ } \\
\text { Country }\end{array}$ & Pakistan & Iran & Iraq & Saudi Arabia & UAE \\
\hline Indicator & $\begin{array}{c}\text { Per capita } \\
\text { Consumption }\end{array}$ & $\begin{array}{c}\text { Per capita } \\
\text { Consumption }\end{array}$ & $\begin{array}{c}\text { Per capita } \\
\text { Consumption }\end{array}$ & $\begin{array}{c}\text { Per capita } \\
\text { Consumption }\end{array}$ & $\begin{array}{c}\text { Per capita } \\
\text { Consumption }\end{array}$ \\
\hline $1995-97$ & 3.8 & 11.3 & 34.7 & 31.4 & 84.1 \\
$1998-00$ & 4.2 & 12.2 & 34.1 & 33.5 & 111.5 \\
$2003-05$ & 2.9 & 12.1 & 24.0 & 38.6 & 164.5 \\
\hline
\end{tabular}

Source: Computation based on data from www.fao.org.

Based on the competitiveness indicators provided in Table-3, the results reveal that Pakistan has a relatively high comparative and competitive advantage in the production of mangoes as against its main competitors. Pakistan's RCA values registered an increasing trend during 1995-97 and 2003-05. India, Brazil, and the Netherlands also increased their comparative advantage over the investigated period, while Mexico showed a significant decrease in its RCA value over the period investigated. Pakistan, Brazil, Mexico, and the Netherlands increased their consumption over the period investigated. The highest consumption was registered in Mexico. India decreased its consumption (Table-4) but increased its comparative advantage.

Table-3: Competitiveness Indicators of Major Mango Exporters

\begin{tabular}{cccccccccccc}
\hline $\begin{array}{c}\text { Period/ } \\
\text { Country }\end{array}$ & \multicolumn{2}{c}{ Pakistan (6) } & \multicolumn{2}{c}{ Brazil (3) } & \multicolumn{2}{c}{ India (1) } & \multicolumn{2}{c}{ Mexico (2) } & \multicolumn{2}{c}{ Netherlands (4) } \\
\hline Indicator & RCA & RCA\# & RCA & RCA\# & RCA & RCA\# & RCA & RCA\# & RCA & RCA\# \\
\hline $1995-97$ & 8.57 & 2.16 & 7.79 & 2.13 & 7.20 & 2.02 & 34.43 & 4.00 & 2.44 & 0.99 \\
$1998-00$ & 23.07 & 3.18 & 11.2 & 2.52 & 6.57 & 1.93 & 22.93 & 3.50 & 2.65 & 1.08 \\
$2003-05$ & 21.60 & 3.11 & 11.54 & 2.58 & 18.8 & 3.13 & 15.77 & 2.96 & 2.94 & 1.20 \\
\hline
\end{tabular}

Source: Computation based on data from www.fao.org. Figures in parentheses indicate the ranking of the country in the world market for dates. RCA = revealed comparative advantage, RCA\# = ln (RXA). 
Table-4: Annual per Capita Consumption of Mangoes (Unit: $\mathrm{kg} /$ person/annum)

\begin{tabular}{cccccc}
\hline $\begin{array}{l}\text { Period/ } \\
\text { Country }\end{array}$ & Pakistan & Brazil & India & Mexico & Netherlands \\
\hline Indicator & $\begin{array}{c}\text { Per capita } \\
\text { Consumption }\end{array}$ & $\begin{array}{c}\text { Per capita } \\
\text { Consumption }\end{array}$ & $\begin{array}{c}\text { Per capita } \\
\text { Consumption }\end{array}$ & $\begin{array}{c}\text { Per capita } \\
\text { Consumption }\end{array}$ & $\begin{array}{c}\text { Per capita } \\
\text { Consumption }\end{array}$ \\
\hline $1995-97$ & 6.6 & 3.4 & 11.3 & 12.7 & 0.6 \\
$1998-00$ & 6.1 & 2.5 & 9.9 & 13.3 & 1.5 \\
$2003-05$ & 7.3 & 4.6 & 10.6 & 12.8 & 1.8 \\
\hline
\end{tabular}

Source: Computation based on data from www.fao.org.

The results presented in Table-5 indicate that Pakistan has a comparative advantage with an increasing trend in orange exports during the periods under analysis. However, Pakistan has the lowest comparative and competitive advantage relative to four major exporters of oranges except the US, which does not have a comparative advantage for the period investigated. South Africa and Morocco have increased their comparative and competitive advantage. Per capita consumption decreased in Pakistan, South Africa, Morocco, and the US, and increased in Spain (Table-6).

Table-5: Competitiveness Indicators of Major Oranges Exporters

\begin{tabular}{cccccccccccc}
\hline $\begin{array}{l}\text { Period/ } \\
\text { Country }\end{array}$ & Pakistan (15) & \multicolumn{2}{c}{ Spain (1) } & \multicolumn{2}{c}{ South Africa (2) } & Morocco (4) & \multicolumn{2}{c}{ USA (3) } \\
\hline Indicator & RCA & RCA\# & RCA & RCA\# & RCA & RCA\# & RCA & RCA\# & RCA & RCA\# \\
\hline $1995-97$ & 1.52 & 0.42 & 25.09 & 3.87 & 7.43 & 2.05 & 75.39 & 4.45 & 0.78 & -0.14 \\
$1998-00$ & 3.05 & 1.12 & 23.65 & 3.75 & 11.35 & 2.49 & 55.44 & 4.12 & 0.77 & -0.15 \\
$2003-05$ & 3.37 & 1.22 & 25.28 & 3.92 & 12.39 & 2.59 & 50.15 & 4.00 & 0.89 & -0.03 \\
\hline
\end{tabular}

Source: Computation based on data from www.fao.org, Figures in parenthesis are rankings of each country in world market in export of oranges. RCA=Revealed Comparative Advantage, RCA\# =1n (RXA) 
Table-6 Annual per Capita Consumption of Oranges (Unit: $\mathrm{kg} /$ person/annum)

\begin{tabular}{lccccc}
\hline $\begin{array}{l}\text { Period/ } \\
\text { Country }\end{array}$ & Pakistan & Spain & South Africa & Morocco & US \\
\hline Indicator & $\begin{array}{c}\text { Per capita } \\
\text { Consumption }\end{array}$ & $\begin{array}{c}\text { Per capita } \\
\text { Consumption }\end{array}$ & $\begin{array}{c}\text { Per capita } \\
\text { Consumption }\end{array}$ & $\begin{array}{c}\text { Per capita } \\
\text { Consumption }\end{array}$ & $\begin{array}{c}\text { Per capita } \\
\text { Consumption }\end{array}$ \\
\hline $1995-97$ & 10.5 & 32.8 & 11.3 & 18.8 & 37.2 \\
$1998-00$ & 9.2 & 34.2 & 13.4 & 20.6 & 37.3 \\
$2003-05$ & 8.8 & 36.2 & 10.4 & 18.1 & 32.1 \\
\hline
\end{tabular}

Source: Computation based on data from www.fao.org.

\section{Conclusion}

The main objective of this paper was to examine the export competitiveness of dates, oranges, and mangoes for Pakistan and its main competitors during the period 1995-2005.

The results revealed that Pakistan has a higher comparative and competitive advantage in the production of dates and mangoes relative to its main competitors during the period analyzed. The results also revealed that Pakistan has the lowest comparative and competitive advantage relative to the world's four major exporters of oranges, except the US. However, Pakistan has significantly increased its comparative and competitive advantage over the examined period for all commodities under analysis. Among these commodities, dates have a higher advantage than oranges and mangoes for Pakistan. Based on the results, it was observed that Pakistan's main competitors in date exports have decreased their competitiveness, while for mangoes and oranges, their comparative and competitive advantage has increased slightly. Per capita consumption of mangoes has increased in Pakistan, while dates and oranges showed a decreasing pattern during the entire period under analysis. In oranges, all countries included in the analysis except Spain showed a decreasing consumption trend.

The increasing pattern of RCA and the decreasing trend in domestic consumption of dates and oranges in Pakistan indicates that there is potential for higher growth in these products and these products can be a source of higher export earnings, which advocates the need for strengthening the country's competitiveness in these exports. 


\section{References}

Akhtar, M.R. (1999). Effects of Trade liberalization on Agriculture in Pakistan: Commodity Aspects. Working Paper 44, the CGPRT Centre, Bogor Indonesia.

Azhar, R.A. (1995). The Uruguay Round and Pakistan's Exports: In the Implications of Uruguay Round for Pakistan. Pakistan Institute of Development Economics, Islamabad, Pakistan.

Balassa, B. (1965). Trade Liberalization and Revealed Comparative Advantage. The Manchester School of Economics and Social Studies, $33,92-123$.

Balassa, B. (1989). Comparative Advantage, Trade Policy and Economic Development. London: Harvester Wheatsheaf.

Bender, S. and Li, K.W. (2002). The Changing Trade and Revealed Comparative Advantages of Asian and Latin American Manufacture Exports. Center Discussion Paper No. 843, Yale University, Economic Growth Center.

Dalum, B., K. Laursen, and Villumsen, G. (1998). Structural Change in OECD Export Specialization Patterns: De-Specialization and Stickiness. International Review of Applied Economics, 12(3), 423-43.

Faruqee, R. (1995). Structural and Policy Reforms for Agricultural Growth: The Case for Pakistan. The Agricultural and Natural Resource Division, South Asia Department, the World Bank.

Ferto, I. and Hubbard, L.J. (2003). The Dynamics of Agri-Food Trade Patterns: The Accession Countries' Case. Proceedings International Conference Agricultural Policy Reform and the WTO: Where are we heading? Capri, Italy, June 23-26.

Food and Agricultural Organization (2008). "Food and Agricultural Organization, Statistics Division 2008, http: //www.fao.org.

Frohberg, K., and Hartmann, M. (1997). Comparing Measures of Competitiveness. Discussion Paper No. 2, Institute of Agricultural Development in Central and Eastern Europe, Germany. 
Government of Pakistan (2006-07). Fruit Vegetables and Condiments Statistics of Pakistan, Ministry of Food Agriculture and Livestock, Economic Trade and Investment Wing, Islamabad.

Khan. S. (2000). Agriculture and the New Trade Agenda in the WTO 2000 Negotiations: Economic Issues and Policy Options for Pakistan. Mimeo, The World Bank.

Mahmood, A. (2005). Export Competitiveness and Comparative Advantage of Pakistan's Non-Agricultural Production Sectors: Trends and Analysis. Pakistan Institute of Development Economics, Paper presented at Twentieth Annual General Meeting \& Conference, Islamabad, Pakistan.

Laursen, K. (1998). Revealed Comparative Advantage and the Alternatives as Measures of International Specialization. DRUID Working Paper No. 98-30, Copenhagen Business School, Department of Industrial Economics and Strategy/Aalborg University, Department of Business Studies.

Hsu, J.L. and Wann, J.J. (2001). Competitiveness and Consumer Preference of US Fruits in Taiwan. Proceedings of the Annual Meetings of the American Agricultural Economics Association-Canadian Agricultural Economics Society, Chicago, USA August 5-8.

Prasad, R.N. (2004). Fiji's Export Competitiveness: A Comparison with Selected Small Island Developing States. Working Paper 2004/06, Economics Department Reserve Bank of Fiji.

Scott, L. and Vollrath, T.L. (1992). Global Competitive Advantage and Overall Bilateral Complementarity in Agriculture: A Statistical Review. United States Department of Agriculture, Economic Research Service, Statistical Bulletin, No. 850. Washington D.C.

Vollrath, T.L. (1985). Dynamics of Comparative Advantage and the Resistance to Free Trade, Washington D.C. USDA, ERS, Foreign Agricultural Economics Report, Number 214.

Vollrath, T.L. and Huu, V. (1988). Investigating the Nature of World Agricultural Competitiveness, Washington D.C. USDA, ERS.

Vollrath, T.L. (1991). A Theoretical Evaluation of Alternative Trade Intensity Measures of Revealed Comparative Advantage. Weltwirtschaftliches Archiv, 127(2), 265-280. 